\title{
HLA type, islet cell antibodies, and glucose intolerance in cystic fibrosis
}

\author{
P R STUTCHFIELD, ${ }^{*}$ S M O'HALLORAN, ${ }^{*}$ C S SMITH, ${ }^{*} \mathrm{~J}$ C WOODROW, $\dagger$ \\ G F BOTTAZZO, $\ddagger$ AND D HEAF*
}

*Department of Child Health, Royal Liverpool Children's Hospital Alder Hey, tDepartment of Medicine, Royal Liverpool Hospital, and $\ddagger$ Department of Immunology, University College Middlesex Medical School, London

SUMMARY Impaired glucose tolerance, assessed by a raised glycated haemoglobin ( $\left.\mathrm{HbA}_{1}\right)$ concentration, was found in $24(39 \%)$ out of 61 patients with cystic fibrosis with an age range of 1-23 years. No correlation between age and $\mathrm{HbA}_{1}$ concentration was found indicating that factors other than progressive pancreatic fibrosis may be important in the aetiology. HLA typing, islet cell antibodies, and autoantibody screen were completed. Eighteen (75\%) out of 24 patients with cystic fibrosis who had an impaired glucose tolerance had HLA-DR3 or HLA-DR4 antigens compared with $23(62 \%)$ out of 37 patients with normal glucose tolerance. Islet cell antibodies were present in seven (15\%) out of 46 patients with cystic fibrosis; the prevalence in a normal population is $0 \cdot 5 \%$. Five $(25 \%)$ of the 20 patients with a raised $\mathrm{HbA}_{1}$ concentration were positive for islet cell antibodies compared with two (8\%) out of the 26 with normal glucose tolerance. Six $(86 \%)$ out of seven patients who were positive for islet cell antibodies had HLA-DR3 or HLA-DR4 antigens. There was no general autoantibody production. Islet cell antibodies may play a part in the development of glucose intolerance in some patients with cystic fibrosis by being produced in those who are genetically predisposed as part of an immune response to damaged pancreatic tissue.

The incidence of insulin dependent diabetes in patients with cystic fibrosis is reported to be $1-10 \%{ }^{1-3}$; this is many times the incidence in a normal population. ${ }^{4}$ Glucose intolerance occurs in $8-75 \%$. ${ }^{1}$ Early studies suggested that glucose intolerance develops in patients with cystic fibrosis secondary to pancreatic damage after exocrine pancreatic disease rather than in association with juvenile onset diabetes. Increasing disruption of islet cells without decrease in islet cell number was found with increasing age, as a result of progressive pancreatic fibrosis. ${ }^{5}$ It was proposed that the islet cell disruption led to the delayed and impaired release of insulin, leading to glucose intolerance. Immunohistochemical techniques, however, have shown a reduced islet and $\beta$ cell number in patients with cystic fibrosis who have insulin dependent diabetes. $^{236}$ In addition, a lack of correlation between glucose intolerance, age, and Shwachman score has been reported. ${ }^{2} 7$ These findings suggest that aetiological factors other than progressive pancreatic fibrosis may contribute to the development of glucose intolerance and insulin dependence.
The increased familial incidence and the association with HLA genes B8, B15, and in particular DR3 and DR4, indicates that genetic factors are important in the aetiology of type $I$ insulin dependent diabetes. ${ }^{8-11}$ In patients with cystic fibrosis no association has been found so far between HLA type and insulin dependent diabetes. ${ }^{12}$

Islet cell antibodies have been reported in a high proportion of patients with insulin dependent diabetes at diagnosis, but are less common as the duration of the disease increases. ${ }^{11}$ The presence of islet cell antibodies may precede the development of overt symptomatology in predisposed people, ${ }^{13}{ }_{14}^{14}$ but their role in the pathogenesis is unclear. It is debatable whether they produce direct islet cell damage $^{15}$ or serve only as markers for islet cell destruction. ${ }^{16}$ Antibodies to human pancreas have been shown in patients with cystic fibrosis ${ }^{17}$ but the presence of islet cell antibodies has not been reported. An increased incidence of autoantibodies to smooth muscle, ${ }^{18}$ reticulin, ${ }^{19}$ and lung $^{17}$ and antinuclear antibodies ${ }^{20}$ have been found in patients with cystic fibrosis. 
The aim of this study was to determine possible genetic and autoimmune factors in the aetiology of glucose intolerance and insulin dependent diabetes in a group of patients with cystic fibrosis. The HLA type and presence of a variety of autoantibodies, including islet cell antibodies was investigated and related to the presence of glucose intolerance in these patients.

\section{Patients and methods}

Sixty one of the 64 patients attending the clinic for cystic fibrosis at Alder Hey Children's Hospital between January and June 1985 were entered into this study. Their mean (SD) age was $9(5 \cdot 3)$ years, range 1-23 years. The presence of glucose intolerance was assessed at the time of recruitment by measuring the concentration of glycated haemoglobin $\left(\mathrm{HbA}_{1}\right)$. This was repeated at intervals of two to six months for a period of one year. A standard oral glucose tolerance test $(1.75 \mathrm{~g} / \mathrm{kg}$ glucose, maximum $75 \mathrm{~g})^{21}$ was completed on patients with a raised $\mathrm{HbA}_{1}$ concentration and where possible patients with cystic fibrosis with a normal $\mathrm{HbA}_{1}$ who were of similar age. ${ }^{22}$ None of the patients was taking drugs that could influence glucose tolerancefor example, steroids or salbutamol-and none had acute infections at the time of the study. No patient was iron deficient on haematological assessment. Blood was taken for HLA typing and autoantibody screen. The severity of cystic fibrosis was assessed using the Shwachman score ${ }^{23}$ pulmonary function tests, and Chrispin-Norman $x$ ray score. ${ }^{24}$

$\mathrm{HbA}_{1}$ concentrations were determined by exchange column chromatography and spectrophotometry (Biorad haemoglobin $\mathrm{A}_{1}$, by column test) and expressed as a percentage of the total haemoglobin. The between assay standard deviation for this method was 0.68 and the coefficient of variation was $5.7 \%$. The reference range for our laboratory is $5 \cdot 3-8.8 \% \quad \mathrm{HbA}_{1}$; representing 2SD limits of the mean of a normal paediatric population. A value of $\mathrm{HbA}_{1}$ above $9 \%$ was considered as raised. Patients were considered to show impaired glucose tolerance if an abnormal oral glucose tolerance test or a raised $\mathrm{HbA}_{1}$ concentration, or both, was shown.

HLA typing for $\mathrm{A}, \mathrm{B}$, and $\mathrm{Cw}$ specificities was carried out by a standard two stage lymphocytotoxicity microassay ${ }^{25}$ and for DR specificities by the two colour fluorescence method. ${ }^{26}$ Controls were healthy individuals residing in the same geographical area as the patients and included 550 typed for HLA-A, B, and Cw specificities and 232 for the DR specificities.

Plasma obtained for autoantibody tests was frozen $\left(-20^{\circ} \mathrm{C}\right)$ before and during transport to the Middlesex
Hospital for analysis. Conventional islet cell antibodies and complement fixing islet cell antibodies were determined by following a standard protocol recently used for the standardisation of islet cell antibodies. $^{27}$ The samples were tested without knowledge of the patients' details and the results confirmed by at least two independent observers. Using the same conditions for the pancreas, reagent, and incubation, the putative islet cell antibody standards currently being assessed by the immunology and diabetes workshops gave end point titres of 32 when tested 'blind' on two occasions. ${ }^{28}$ Samples were read by two independent observers and the interassay reproducibility was one doubling dilution. Weakly positive reactions were confirmed on several human blood group $\mathrm{O}$ pancreases by different observers.

The autoantibody screening included gastric parietal cell antibody and a variety of non-organ specific antibodies-for example, antinuclear and mitochondrial. ${ }^{29} 30$ Thyroglobulin and thyroid microsomal antibodies were determined by passive haemagglutination using commercial kits (Wellcome, thymune).

Ethical committee approval for the study was given and parental consent obtained.

\section{Results}

CLINICAL ANALYSIS

On entry into the study, 21 of the 61 patients with cystic fibrosis were found to have a raised $\mathrm{HbA}_{1}$ concentration: mean $10 \cdot 6 \%$, range $9 \cdot 1-17 \cdot 5 \%$. During the course of the first year a further three patients were identified with a high value. An oral glucose tolerance test was completed on 21 of these 24 patients; seven were glucose intolerant, three of these producing a diabetic response, two of whom are insulin dependent. Insulin treatment in these two patients, aged 17 and 19 years, had been started two and four years before entry into the study. Their diabetes was well controlled at this time as shown by the $\mathrm{HbA}_{1}$ concentrations recorded (fig 1). Evidence of impaired $\beta$ cell function in the 14 patients with a normal oral glucose tolerance test but raised $\mathrm{HbA}_{1}$ concentration has been previously reported. ${ }^{22}$ The mean (SD) $\mathrm{HbA}_{1}$ concentration on entry to the study of the remaining 40 patients was $7 \cdot 8(0.9) \%$, range $5 \cdot 9-8 \cdot 8 \%$; this is comparable with the $7 \cdot 4$ $(0.94) \%$ found in a normal population. An oral glucose tolerance test was completed on 13; all showed normal glucose tolerance. As many patients as possible were recruited. Parents were reluctant to agree to further drip siting and blood taking when their child was well when there was no evidence of glucose intolerance. 


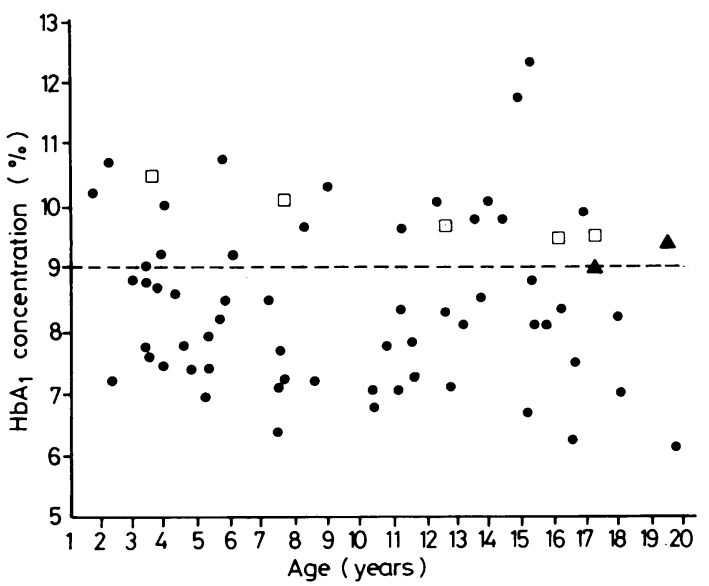

Fig 1 Initial $H b A_{1}$ concentration recorded on each patient on entry to study plotted against age. $\square=$ patients with confirmed glucose intolerance and $\boldsymbol{\Lambda}=$ insulin dependent patients. The dotted line represents the upper limit of the normal range $-2 S D$ above the mean.

No correlation was found between the concentration of $\mathrm{HbA}_{1}$ and age (fig 1). Those patients shown to be glucose intolerant by the oral glucose tolerance test are indicated; the youngest was aged 3 years 8 months. No correlation was found between Shwachman score and $\mathrm{HbA}_{1}$ concentration but as expected there was a significant positive correlation between age and Shwachman score.

\section{HLA STUDIES}

HLA typing was completed on all 61 patients. The relative frequency of each antigen was compared with a Liverpool population after exclusion of one of each of the five sibling pairs in the population of patients with cystic fibrosis. An increase in the frequency for HLA-Al $(p=0.07)$, HLA-A28 $(p=0.0025)$, and HLA-DR6 $(p=0.026)$ was seen in 56 patients with cystic fibrosis, but correction for the 42 specificities tested for showed that none of these increases was significant.

Dividing the patients with cystic fibrosis including sibling pairs, into (a) those with glucose intolerance as shown by the oral glucose tolerance test, (b) those with a raised $\mathrm{HbA}_{1}$ concentration (including those in (a)), and (c) those with no evidence of glucose intolerance by either the oral glucose tolerance test or $\mathrm{HbA}_{1}$, the relative frequencies of HLA-DR3 and HLA-DR4 antigen are compared with the Liverpool population (fig 2). The relative frequency of HLADR3 was highest in patients with cystic fibrosis who had impaired glucose tolerance, although this was not significant. Eighteen $(75 \%)$ of the 24 patients with cystic fibrosis who had evidence of impaired glucose tolerance had HLA-DR3 or HLA-DR4 antigen compared with $23(62 \%)$ of the 37 patients with normal glucose tolerance.

\section{ISLET CELL AND OTHER ANTIBODY STUDIES}

The screening was completed in 46 of the 61 patients with cystic fibrosis; 20 of these had raised $\mathrm{HbA}_{1}$ concentrations recorded during the one year study including six who were glucose intolerant by an oral glucose tolerance test. Repeat samples were not obtained during the study period. It was not possible to obtain appropriate blood samples on all patients. Conventional islet cell antibodies were present in seven $(15 \%)$ of 46 patients (the prevalence in the normal population is $0.5 \%$ ); this increase is significant, $p<0 \cdot 001$. The two patients who were insulin dependent out of the six in the glucose intolerant group had islet cell antibodies in addition to three of the 14 patients with a raised $\mathrm{HbA}_{1}$ concentration but a normal oral glucose tolerance test. This gives a prevalence of islet cell antibodies in those patients with cystic fibrosis who have evidence of impaired glucose tolerance of $25 \%$ (five out of 20 ). The remaining two patients with conventional islet cell antibodies showed no evidence of glucose intolerance; this gave a prevalence of $8 \%$ (two out of 26 ) in the group with no evidence of glucose intolerance. One of these had complement fixing islet cell antibodies. Further details of these patients are shown in table 1 . The patients who were positive for islet cell antibodies were aged 11 to 23 years. Nineteen of the 46 patients tested for islet cell

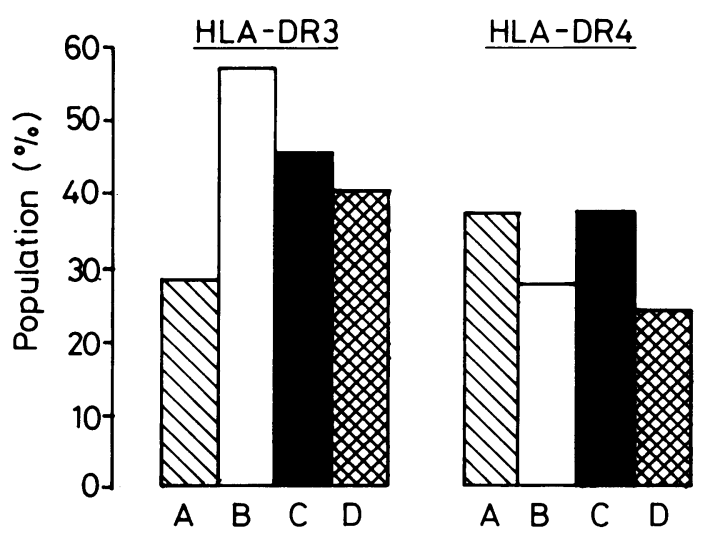

Fig 2 HLA-DR3 and HLA-DR4 antigen frequencies in defined populations $\mathbb{\mathbb { N }}=$ Liverpool population $(n=232)$; $\square=$ patients with cystic fibrosis who were glucose intolerant $(n=7) ; \square=$ patients with cystic fibrosis with a raised $\mathrm{HbA}$, concentration, including the glucose intolerant patients $(n=24) ;$ and $=$ patients with a normal oral glucose tolerance test and $\mathrm{HbA}$, concentration $(n=37)$. 


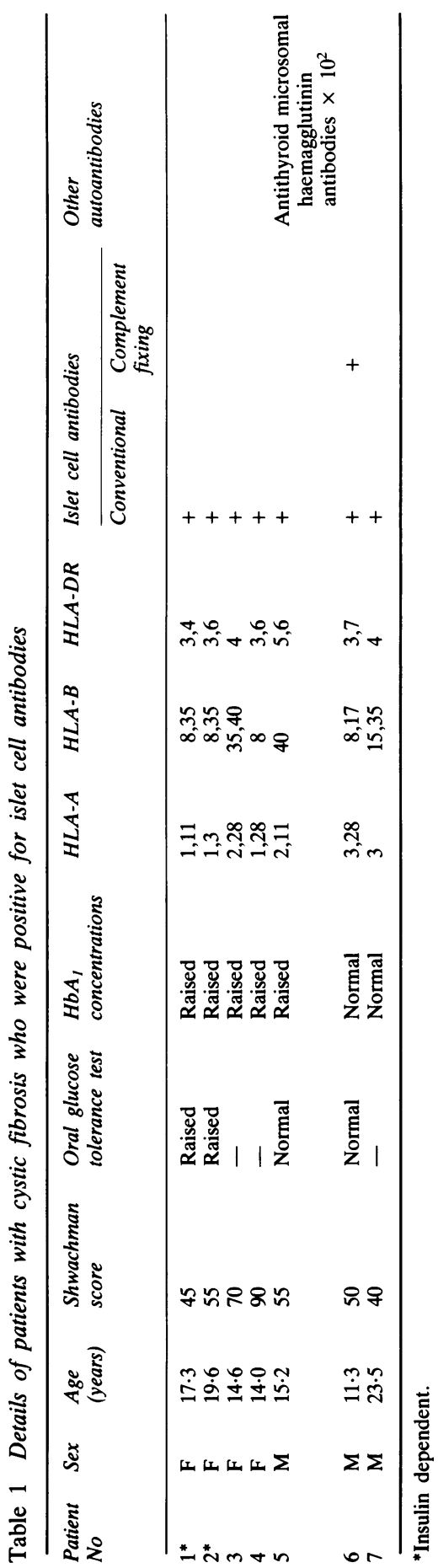

antibodies were in this age group giving an incidence of $37 \%$ (seven out of 19 ). The mean (SD) Shwachman score $(58(17))$ for patients with islet cell antibodies did not differ significantly from patients without $(65(18))$ in this age group or with the glucose intolerant patients (mean 62 (16)); this indicates that they did not have more severe clinical disease. Six $(85 \%)$ out of seven patients who were positive for islet cell antibodies had HLA-DR3 or HLA-DR4 antigen. Only one patient had other autoantibodies present in addition to islet cell antibodies (patient 5 , table 1 ).

The results of the HLA typing and autoantibody tests in the patients shown to be glucose intolerant by an oral glucose tolerance test are shown in table 2. The ages ranged from 3.6-19.6 years. Two of these patients (as discussed earlier) had islet cell anti-bodies detected and only one antinuclear antibodies.

There was no family history of insulin dependent diabetes in the patients with cystic fibrosis in this study, and there were no sibling pairs in the group who were positive for islet cell antibodies or were glucose intolerant. Maturity onset diabetes developed in one grandparent of two patients (patients 5 and 6 , table 1).

Three patients had diffuse antinuclear antibodies, an overall prevalence of $7 \%$ (three out 46 ), and one in addition had parietal cell antibodies. Two of these had mild lung disease as assessed by Shwachman score, lung function tests, and scores on chest radiography.

\section{Discussion}

Evidence of impaired glucose tolerance was found in $39 \%(24 / 61)$ of patients with cystic fibrosis as assessed by a raised $\mathrm{HbA}_{1}$ concentration. Factors that could produce glucose intolerance in these patients were excluded. There was no evidence of penicilloylated haemoglobin causing falsely raised $\mathrm{HbA}_{1}$ concentrations. ${ }^{31}$ All patients were given prophylactic antibiotics; 40 had $\mathrm{HbA}_{1}$ concentrations within the normal range. Patients with raised $\mathrm{HbA}_{1}$ had impaired and delayed $C$ peptide response to oral glucose loading indicating impaired $\beta$ cell function. $^{22}$ Two patients with cystic fibrosis developed insulin dependent diabetes, an incidence of $3 \%$. The increased incidence of glucose intolerance and diabetes found in this study is in accordance with the findings of others. ${ }^{1-3}$ The reported lack of correlation between age and glucose intolerance was confirmed, ${ }^{27}$ indicating that aetiological factors other than pancreatic islet cell disruption with progressive fibrosis may be important in the development of glucose intolerance and diabetes in some patients with cystic fibrosis. 
1238 Stutchfield, O'Halloran, Smith, Woodrow, Bottazzo, and Heaf

Table 2 Details of patients with cystic fibrosis who were glucose intolerant (by oral glucose tolerance test)

\begin{tabular}{|c|c|c|c|c|c|c|c|c|c|}
\hline \multirow{2}{*}{$\begin{array}{l}\text { Patient } \\
\text { No }\end{array}$} & \multirow[t]{2}{*}{ Sex } & \multirow{2}{*}{$\begin{array}{l}\text { Age } \\
\text { (years) }\end{array}$} & \multirow{2}{*}{$\begin{array}{l}\text { Shwachman } \\
\text { score }\end{array}$} & \multirow[t]{2}{*}{$H L A-A$} & \multirow[t]{2}{*}{$H L A-B$} & \multirow[t]{2}{*}{$H L A-D R$} & \multicolumn{2}{|c|}{ Islet cell antibodies } & \multirow{2}{*}{$\begin{array}{l}\text { Other } \\
\text { autoantibodies }\end{array}$} \\
\hline & & & & & & & Conventional & Complement fixing & \\
\hline 8 & $\mathbf{M}$ & $3 \cdot 6$ & 80 & 3,11 & 13,18 & 3,7 & - & - & \\
\hline 9 & F & $9 \cdot 1$ & 75 & 1,9 & 7,8 & 2,3 & - & - & \\
\hline 10 & $\mathbf{F}$ & $13 \cdot 3$ & 80 & 3,9 & 7 & 5,6 & - & - & \\
\hline 11 & M & $16 \cdot 2$ & 50 & 10,11 & 18,27 & 2,4 & - & - & $\begin{array}{l}\text { Antinuclear antibody } \\
\text { diffuse }\end{array}$ \\
\hline 12 & $M$ & $17 \cdot 5$ & 50 & 1,9 & 5,12 & 5,6 & - & - & \\
\hline $1^{*}$ & $\mathrm{~F}$ & $17 \cdot 3$ & 45 & 1,11 & 8,35 & 3,4 & + & - & \\
\hline $2^{*}$ & $\mathrm{~F}$ & $19 \cdot 6$ & 55 & 1,3 & 8,35 & 3,6 & + & - & \\
\hline
\end{tabular}

${ }^{*}$ Insulin dependent.

Genetic linkage between the cystic fibrosis and a diabetogenic associated gene is unlikely as there is no increased incidence of cystic fibrosis in families with insulin dependent diabetes. Schwarz et al reported the results of HLA typing on six patients with cystic fibrosis who developed diabetes mellitus. ${ }^{12}$ Only two of these patients had HLADR3 or HLA-DR4 antigens in contrast with 53 out of 55 children with insulin dependent diabetes also included in the study. The high incidence of HLADR3 or HLA-DR4 antigens in this latter group is consistent with the strong association between these alleles and insulin dependent diabetes reported elsewhere. ${ }^{8}$ The relative risk of developing diabetes is increased five times in any individual with the inheritance of HLA, DR3, or DR4 phenotype. ${ }^{8}$ The evidence suggests that the genes which confer susceptibility to the development of insulitis are in linkage disequilibrium with HLA-DR3 or HLADR4, although recent evidence suggests that the direct involvement of the DQ $\beta$ gene at an adjacent locus may be more significant. ${ }^{32}$ We found an increase in HLA-DR3 antigen in the patients with cystic fibrosis in this study particularly in the patients shown to be glucose intolerant. This was not significant, however, possibly because of the small number of patients in this study. Both of the patients with cystic fibrosis who had insulin dependent diabetes had HLA-B8 and HLA-DR3 in addition to islet cell antibodies. Their diabetes, however, has followed the course characteristic of patients with cystic fibrosis rather than juvenile onset diabetes. Neither had a family history of diabetes and no episodes of ketoacidosis have occurred despite recurrent chest infections. In addition the insulin dosage required to obtain reasonable diabetic control was moderate with insulin dosages of 0.8 and 1.3 units $/ \mathrm{kg} / 24$ hours.

Islet cell antibodies were detected in seven out of $46(15 \%)$ of the patients with cystic fibrosis investigated, six of whom had HLA-DR3 or HLA-DR4 antigens. All were older than 11 years giving an incidence in the 11-23 year age group of $37 \%$. Dividing the patients into two groups, five out of 20 $(25 \%)$ patients with cystic fibrosis who had evidence of impaired glucose tolerance as assessed by $\mathrm{HbA}_{1}$ were positive for islet cell antibodies compared with two out of $26(8 \%)$ of those with normal glucose tolerance. This difference is not significant possibly because of the small number of patients studied but it shows an interesting trend. It is known that the presence of islet cell antibodies may precede the development of glucose intolerance by a number of years. These patients will be studied prospectively to determine the final outcome.

The incidence of islet cell antibodies in a normal population detected in our laboratory is $0.5 \%$ comparable with that reported by others $(0.5 \%$ of 434 control subjects). ${ }^{11}$ In patients with insulin dependent diabetes the prevalence of islet cell antibodies is reported to be dependent on the duration of the diabetes. The presence of islet cell antibodies more than five years after diagnosis was positively correlated with the presence of HLA-A1 and HLA-B8 ${ }^{11}$; these were present in both our diabetic patients. There is evidence that the onset of type I diabetes is slow and develops over several years. ${ }^{131433} \beta$ Cell function may deteriorate gradually during this time with clinical presentation possibly precipitated by a viral infection. ${ }^{34}$ The increased incidence of islet cell antibodies in our patients with cystic fibrosis may reflect that in those patients who have a genetic predisposition an autoimmune response may be mounted to damaged pancreatic tissue with the production of antibodies to islet cells. This may result in further $\beta$ cell destruction. Evidence of impaired $\beta$ cell function was present in five out of seven $(71 \%)$ patients positive for islet cell antibodies at the time of the study. The production of these antibodies was not seen to be part of a generalised autoantibody response to increased antigenic stimulation as only 
one patient positive for them had other autoantibodies present.

In conclusion, evidence of impaired glucose tolerance was found in 24 out of $61(39 \%)$ of the patients with cystic fibrosis who were studied. There was no correlation with age suggesting that factors other than increasing pancreatic fibrosis may be responsible for impaired islet cell function. An increased prevalence of islet cell antibodies was found in the population of patients with cystic fibrosis particularly those with evidence of impaired $\beta$ cell function. We postulate that islet cell antibodies may play a part in the development of glucose intolerance in a proportion of these patients, being produced in genetically predisposed individuals as part of an autoimmune response to damaged pancreatic tissue.

We thank Mrs D Bolger and Mrs S Longworth for typing this paper.

\section{References}

1 Green OC. Endocrinological complications associated with cystic fibrosis. In: Lloyd Still JD, ed. Textbook of cystic fibrosis. 1st ed. Bristol: John Wright, 1983:329-50.

2 Rodman HM, Doershuk CF, Roland JM. The interaction of two diseases: diabetes mellitus and cystic fibrosis. Medicine 1986;65:389-97.

3 Ianucci A, Mukai K, Johnson D, Burke B. Endocrine pancreas in cystic fibrosis, an immunohistochemical study. Hum Pathol 1984;15:278-84.

${ }^{4}$ Beardmore M, Reid JJA. Diabetic children. Br Med J 1966;ii: 1383-4.

5 Handwerger S, Roth J, Gorden P, di Sant' Agnese P, Carpeter DF, Georges P. Glucose intolerance in cystic fibrosis. $N$ Engl J Med 1969;281:451-61.

6 Soejima K, Landug BH. Pancreatic islets in older patients with cystic fibrosis with and without diabetes mellitus: morphometric and immunocytologic studies. Pediatr Pathol (in press).

7 Bistritzer T, Sack J, Eshkol A, Katznelson D. Haemoglobin $A_{1}$ and pancreatic beta cell function in cystic fibrosis. Isr J Med Sci 1983;19:600-3.

${ }^{8}$ Wolf E, Spencer KM, Cudworth AG. The genetic susceptibility to type I (insulin dependent) diabetes: analysis of the HLA-DR association. Diabetologia 1983;24:224-30.

9 Craighead JE. Current views on the etiology of diabetes mellitus. N Engl J Med 1978;299:1439-45.

${ }^{10}$ Cudworth AG, Gorsuch AN, Wolf E, Festenstein H. A new look at HLA genetics with particular reference to type I diabetes. Lancet 1979;ii:389-90.

$"$ Irvine WJ, McCallum CJ, Gray RS, et al. Pancreatic islet cell antibodies in diabetes mellitus correlated with the duration and type of diabetes, coexistent autoimmune disease and HLA type. Diabetes 1977;26:138-47.

12 Schwarz HP, Bonnard GD, Neri TM, Braga S, Zuppinger KA. Histocompatibility antigens in patients with cystic fibrosis and diabetes mellitus. J Pediatr 1984;104:799-800.

13 Gorsuch AN, Spencer KM, Lister J, et al. Evidence for a long prediabetic period in type I (insulin dependent) diabetes mellitus. Lancet $1981 ;$;i: $1363-5$.

14 Tarn AC, Smith CP, Spencer KM, Bottazzo GF, Gale EAM. Type I (insulin dependent) diabetes: a disease of slow clinical onset? Br Med J 1987;294:342-5.
15 Dobersen MJ, Scharff JE, Ginsberg-Fellner F, Notkins AL. Cytotoxic autoantibodies to beta cells in the serum of patients with insulin dependent diabetes mellitus. $N$ Engl J Med 1980;26:1493-8.

16 Wilkin T, Armitage M. Markers for insulin dependent diabetes: towards early detection. $\mathrm{Br}$ Med J 1986;293:1323-6.

${ }^{17}$ Stein AA, Manlapas FC, Soike KF, Patterson PR. Specific isoantibodies in cystic fibrosis. J Pediatr 1964;65:495-500.

${ }^{18}$ Hodson ME, Turner-Warwick M. Autoantibodies in cystic fibrosis. Clin Allergy 1981;11:565-70.

19 Wallwork JC, Brenchley P, McCarthy J, et al. Some aspects of immunity in patients with cystic fibrosis. Clin Exp Immunol 1974;18:303-20.

${ }^{20}$ Hoiby N, Wilk A. Antibacterial precipitins and autoantibodies in serum of patients with cystic fibrosis. Scandinavian Journal of Respiratory Disease 1975;56:38-46.

21 Teuscher A, Jarrett RJ. Diabetes mellitus: diagnostic criteria. Diabetic Medicine 1984;1:305-7.

22 Stutchfield PR, O'Halloran S, Teale JD, Isherwood D, Smith CS, Heaf D. Glycosylated haemoglobin and glucose intolerance in cystic fibrosis. Arch Dis Child 1987;62:805-10.

23 Shwachman H, Kulczycki LL. Longterm study of one hundred and five patients with cystic fibrosis. Am J Dis Child 1958;96: 6-15.

${ }^{24}$ Chrispin AR, Norman AP. The systematic evaluation of the chest radiograph in cystic fibrosis. Pediatr Radiol 1974;2:101-6.

25 Terasaki PI, McClelland JD. Microdroplet assay of human serum cytotoxins. Nature 1964;204:998-1000.

${ }^{26}$ van Rood JJ, van Leeuwen A, Ploem JS. Simultaneous detection of two cell populations by two colour fluorescence and application to the recognition of B cell determinants. Nature 1976;262:795-7.

27 Gleichmann H, Bottazzo GF. Progress toward standardization of cytoplasmic islet cell-antibody assay. Diabetes 1987;36: 578-84.

${ }^{28}$ Bonifacio E, Dawkins RL, Lernmark A. Report of the 2nd international workshop on the standardisation of cytoplasmic islet cell antibodies. Diabetologia 1987;30:273.

29 Scherbaum WA, Mirakain R, Pujol-Borrell R, Dean BM, Bottazzo GF. Immunocytochemistry in the study and diagnosis of organ-specific autoimmune diseases. In: Polak JM, Van Noorden S, eds. Immunocytochemistry: modern methods and applications. Bristol: J Wright, 1986:456-76.

30 Scherbaum WA, Blaschek M, Berg PA, Doniach D, Bottazzo GF. Spectrum and profiles of non-organic autoantibodies in autoimmune diseases. In: Polak JM, Van Noorden S, eds. Immunocytochemistry: modern methods and applications. Bristol: J Wright, 1986:477-91.

31 Flückiger R. Glycosylated haemoglobin in cystic fibrosis. Arch Dis Child 1988;63:223-4.

32 Nepom BS, Palmer J, Kim SJ, Hansen JA, Holbeck SL, Nepom GT. Specific genomic markers for the HLA-DQ subregion discriminate between DR4 ${ }^{+}$insulin dependent diabetes mellitus and DR4 ${ }^{+}$seropositive juvenile rheumatoid arthritis. J Exp Med 1986;164:345-50.

33 Ginsberg-Fellner F, Witt ME, Franklin BH, et al. Trial of markers for identifying children at high risk of developing insulin dependent diabetes mellitus. JAMA 1985;254:1469-72.

34 Bottazzo GF. Death of beta cell: homicide or suicide? Diabetic Medicine 1986;3:119-30.

Correspondence to Dr PR Stutchfield, Department of Child Health, Royal Liverpool Children's Hospital Alder Hey, Eaton Road, Liverpool L12 2AP.

Accepted 5 April 1988 